\title{
THE EFFECT OF LEADERSHIP STYLE, INCENTIVES AND MOTIVATION ON EMPLOYEE WORK ACHIEVEMENT AT THE OFFICE OF THE CLEANLINESS ENVIRONMENTALAGENCY (BLHK) KOTA LANGSA
}

\author{
Likdanawati $^{1}$, Hamdiah $^{2}$, Saiful Harif ${ }^{3}$ \\ ${ }^{1,2,3}$ Faculty of Economics and Business, Universitas Malikussaleh \\ E-mail: likdanawati@unima.ac.id
}

\begin{abstract}
This study aims to determine and analyze the Effect of Leadership Style, Incentives and Motivation on Employee Work Achievement at the Langsa City Office of Environmental Sanitation (BLHK). The research sample of 45 respondents Officer at the Office (BLHK). The variable used is the dependent variable is Employee Job Performance. while the independent variables are Leadership Style, Incentives and Motivation. This study uses multiple linear regression analysis tools. Hypothesis testing using the $\mathrm{F}$ test found that the variables of Leadership Style, Incentives and Motivation have a significant effect together on Employee Job Performance. While the $t$ test or partially states that the variables of Leadership Style, Incentives and Motivation have a positive and significant effect on Employee Job Performance.
\end{abstract}

\section{Keywords: Employee Work Performance, Leadership Style, Incentives and Motivation}

\section{INTRODUCTION}

Human resources are often referred to as resources, power or human strength (energy / power). Resources are also called sources of power, ability, strength, expertise possessed by humans. Along with the development of technology and changes in the world that are increasingly complex, it requires someone to always refresh their abilities according to the capacity of these changes. Basically, humans have basic potential and abilities that ideally will continue to develop if honed in a sustainable manner. Building a career is one of the developmental tasks that will be passed in the lives of individuals who must continue to improve their abilities in order to build their careers or positions. Otherwise,

In the management of government or agencies, experts are needed and have high work motivation. In addition, employees who have creativity, perseverance and skills are also needed. The success of an organization is greatly influenced by employee performance. Every organization or company will always try to improve employee performance in the hope that the company's goals will be achieved. Human resources are often referred to as human resources, power or human strength (energy or power). Resources are also called sources of power, ability, strength, expertise possessed by humans. Along with the development of technology and changes in the world that are increasingly complex, requires someone to always 
refresh their abilities in accordance with the capacity of the change. Basically, humans have basic potential and abilities that ideally will continue to develop if honed in a sustainable manner. Building a career is one of the developmental tasks that will be passed in the lives of individuals who must continue to improve their abilities in order to build their careers or positions. On the other hand, an organization will also progress and develop if the resources owned by its employees are of good quality. Building a career is one of the developmental tasks that will be passed in the lives of individuals who must continue to improve their abilities in order to build their careers or positions. On the other hand, an organization will also progress and develop if the resources owned by its employees are of good quality. Building a career is one of the developmental tasks that will be passed in the lives of individuals who must continue to improve their abilities in order to build their careers or positions. On the other hand, an organization will also progress and develop if the resources owned by its employees are of good quality.

It can be concluded that the problems in the research in the office (BLHK) of the environmental hygiene agency are the influence of a leader's style in leading or managing a government well so that employees who work within the company can work optimally and produce satisfactory work performance and goals. company is reached. Leadership style is a behavioral norm used by a person when that person tries to influence the behavior of others (Suranta, 2002). The problem of leadership style here is the lack of attention from superiors to their subordinates, resulting in the company losing money, because leadership style greatly influences employee performance.

The style of leadership in an institution is very important aimed at influencing the success of government. The leadership style also affects the performance of employees in the government (BLHK), the better a leader, the better the performance produced by employees. Governments use rewards or gifts and order as tools to motivate employees. Leaders hear ideas from subordinates before making decisions. The right leadership style will lead to a person's motivation to excel. The success or failure of employees in work performance can be influenced by the leadership style of their superiors (Hardini, 2001 in Suranta, 2002). Suranta (2002) and Tampubolon (2007) have examined the effect of leadership style on performance, stating that leadership style has a significant influence on employee performance.

In the management of government or agencies, experts are needed and have high work motivation. In addition, employees who have creativity, perseverance and skills are also needed. The success of an organization is greatly influenced by employee performance. Every organization or company will always try to improve employee performance in the hope that the company's goals will be achieved. To achieve the goals and objectives of the company, it is necessary to have an encouragement so that employees are able to work in accordance with company expectations. In order to further encourage higher work performance, many organizations adopt an incentive system. The problem for early incentives is that employees never get bonuses from the company, even though employees often work overtime outside of their working hours. even though the incentives are very influential on the performance of the employees produced. No less important than incentives, motivation also has an important role 
in improving employee performance in a company. Without work motivation, an employee cannot work optimally and contribute to the company. Motivation is something that creates enthusiasm or work motivation, so that the strength or weakness of employee work motivation determines work performance, because a person's work performance depends on the strength of his motives. Giving this encouragement aims to activate people or employees so that they are enthusiastic and can achieve the desired results (Yusuf, 2015: 263). The provision of incentives is influenced by employee performance and incentives depending on the number of results achieved in the employee's working time and the length of work, incentives are determined on the basis of the length of time the employee carries out or completes a job. The provision of incentives is also influenced by seniority. The more senior an employee is, the higher his loyalty to the organization, and the more stable and calm he is in the organization.

In addition to incentives, another factor that affects employee performance is motivation in carrying out tasks and responsibilities, an employee really needs encouragement to be able to do his job better. This drive is called motivation. Motivation can create morale for employees in government (BLHK) in carrying out their work. Work motivation needs to be improved because it will affect employee performance. If the motivation is high, the employee's work performance will increase and the government's goals can be achieved. In general, motivation can be defined as an encouragement in employees to do as much as possible in carrying out their duties, because they believe that with the success of the organization can achieve its goals and various goals, the personal interests of the members of the organization will be maintained as well (Siagian, 2007: 287)

Motivation also has a problem here, the lack of incentive bonuses so that employees are not stable in carrying out their duties so that the results produced are bad and unstable, because the motivation of an employee is also influenced by how the encouragement from the company. The motive referred to here is the desire and drive that exists in every employee to achieve the target. Someone who has high motivation, he will work hard, maintain the pace of hard work, and have self-controlled behavior towards important goals. Thus, the high motivation that an employee has at work will result in high performance as well. Based on the theory above, the writer concludes, work achievement can be achieved, of course, it is not an easy matter. This requires special handling as well as employee development which greatly influences work performance. with the company's goals, and motivation is no less important as a means to encourage higher employee performance. This includes components that are able to improve work performance.

This research was conducted at the Environmental Hygiene Agency (BLHK) company in Langsa city. Based on a survey conducted by interviewing the performance of employees at the BLHK company, it can be said that the performance of BLHK employees is not optimal, as indicated by the presence of employees who are indifferent to the cleanliness of the city. "The Influence of Leadership Style, Incentives and Motivation on Employee Work Performance at the Office of the Cleansing Environment Agency (BLHK) of Langsa City". 


\section{Formulation of the problem}

Based on the above background, the formulation of the problem in this research is

1. Does leadership style affect employee performance at the Langsa BLHK office?

2. Do incentives affect employee performance at the Langsa BLHK office?

3. Does motivation affect the work performance of employees at the Langsa BLHK office?

4. Which of the three variables has the most dominant effect on employee performance at the Langsa BLHK office?

\section{Research purposes}

Based on the formulation of the problem that has been described, the objectives of this study are:

1. To determine the effect of leadership style on employee performance at the BLHK office in the city of Langsa.

2. To determine the effect of incentives on employee performance at the BLHK office in Langsa city.

3. To determine the effect of motivation on employee performance at the BLHK office in Langsa city.

4. To find out and analyze which variables have the most dominant effect on employee performance at the BLHK Office in Langsa City.

\section{LITERATURE REVIEW}

\section{Theoretical basis}

\section{a. Leadership Style}

Leadership style is a behavioral norm used by a person when that person tries to influence the behavior of others (Suranta, 2002). The leadership style is suitable when the government's goals have been communicated and subordinates have accepted them. A leader must apply a leadership style to manage his subordinates, because a leader will greatly affect the success of the organization in achieving its goals (Waridin and Bambang Guritno, 2005). Governments use rewards or gifts and order as tools to motivate employees. Leaders hear ideas from subordinates before making decisions. The right leadership style will lead to a person's motivation to excel. The success or failure of employees in work performance can be influenced by the leadership style of their superiors (Hardini, 2010). 2001 in Suranta, 2002). Suranta (2002) and Tampubolon (2007) have examined the effect of leadership style on performance, stating that leadership style has a significant influence on employee performance.

Leadership style is the process of influencing others to understand and agree with what needs to be done and how the task is carried out effectively, as well as the process of facilitating individual and collective efforts to achieve common goals (Yukl, 2010).

There are five leadership styles that are adapted according to the situation according to Siagian (2012), namely: 
1. Autocratic type of leader.

2. The militaristic type of leader

3. Charismatic type of leader.

4. Democratic type of leader

The indicators of leadership style according to Kartono (2008) stated as follows:

1. Decision making ability

2. Motivating ability

3. Communication skills

4. Ability to control subordinates

5. Responsibility

6. Ability to control emotions

b. Incentive

Incentives are salary increases that are awarded to an employee at a specified time in the form of a higher base salary, usually based exclusively on individual performance (Dessler, 2013). Hariandja (2011) provides an understanding of incentives by saying that: "Incentives are a form of direct payment that is based or directly linked to performance and profit sharing for employees due to increased productivity or cost savings.

According to Prof. Dr. Lijan Poltak Sinambela, (2018) Incentives are elements or remuneration provided that are not fixed or variable depending on employee performance. Incentives are one of the important drivers that can provide incentives for employees to work more optimally. Through incentives, it is hoped that employees will be able to participate more in carrying out organizational tasks.

According to Sutrisno Edy (2011) the purpose of providing incentives is as follows:

a. Appreciate work performance

b. Guarantee justice

c. Retain employees

d. Get quality employees

e. Cost control

f. Meet the rules.

According to Siagian Sondang P. (2010) the factors that influence the incentive system are as follows:

a. Applicable wage and salary levels

b. Union demands

c. Productivity

d. Organizational policies regarding wages and salaries

e. Laws and regulations

\section{c. Motivation}

Bartol and Martin in Dobre (2013) Work motivation is a powerful tool in strengthening a behavior and triggers a tendency to continue something in other words, 


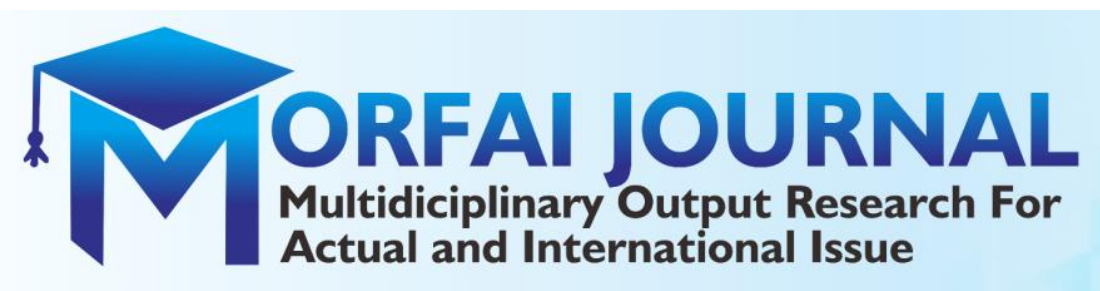

work motivation is an internal drive to fulfill unsatisfactory needs and desires to achieve certain goals.

According to Hasibuan (2012) work motivation is the provision of a driving force that creates one's work enthusiasm, so that they want to work together, work effectively and be integrated with all efforts to achieve satisfaction even work motivation is the best tool for best performance. According to Nawawi (2011), motivation is a condition that encourages or causes someone to do an act or activity that takes place consciously.

The purpose of providing motivation proposed by Sofyandi (2008), is as follows:

a. To increase employee morale and satisfaction

b. Increase employee productivity

c. Maintaining employee stability in the company

d. Improve employee discipline at work

e. Efficient in doubling employees

f. Creating a conducive working atmosphere and relationship.

g. Improve employee welfare.

h. Increase the sense of responsibility for the task, and others

\section{d. Employee Work Performance}

According to Sutrisno (2010) defines achievement as a person's level of speed on tasks that include work. Providing a definition of achievement is a record of the results obtained from the functions of certain jobs or certain activities over a certain period of time, work performance is defined as a person's success in carrying out a job.

Work performance According to Handako (2012) work performance (performance appraisal) is the process through which organizations evaluate and assess is the process through which organizations evaluate and assess employee performance. From the opinion above, it can be concluded that performance appraisal is a process through which organizations evaluate and assess employee performance.

The following are the objectives of the work performance assessment according to (Handoko, 2012) including:

1. Work Performance Improvement.

2. Informational inaccuracy.

3. Career planning and development

4. Placement decisions

5. Training and development needs

6. Staffing process stores

7. Fair job opportunities

Factors that can affect work performance include:

1) Motivation

2) Job satisfaction

3) Stress level 
4) Physical conditions of work

5) Compensation system

6) Compensation system

\section{Conceptual Framework}

Given the importance of human resources, every company must pay attention to the level of ability possessed by its employees. In the company, good work productivity is needed to improve the quality and quality. Leadership style is the style or behavior of a leader in leading a good and bad company in achieving certain company goals. Therefore, in order to be a leadership style, the company must also pay attention to work incentives, employee job satisfaction and motivation. Because leadership style, incentives, and motivation greatly affect employee performance.

Leadership style is a behavior designed by a leader in leading a company as well as possible in nurturing its employees so that the vision and mission that have been set are carried out properly. If a leader lacks a level of awareness in leading a company he leads, it will not produce good employee performance either.

Incentive is an increase in salary given to employees given by the company to him because the company where he works gets more profits, so the employee gets more bonuses that are given outside of his basic salary. Therefore, employees who work in the company certainly expect rewards and bonuses from the company for sure.

Motivation is a mental state that encourages a person to do an activity that is outside the usual circumstances, high spirit attitude and ability to do something related to the achievement of goals, both organizational goals and personal goals of each member.

\section{Figure 1 Conceptual Framework}

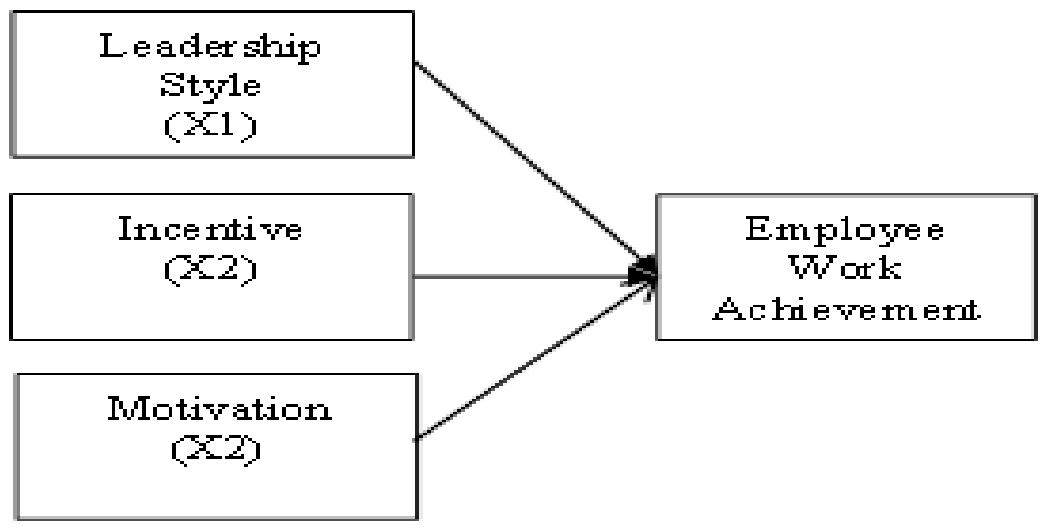

\section{RESEARCH METHOD}

\section{Population and Sample}

According to Sugiyono (2009), the population is a generalization area consisting of subjects or objects that have certain qualities and characteristics set by researchers to be studied 
and then drawn conclusions. The population in this study is all employees who work in the Langsa City Office (BLHK) as many as 45 employees

According to Sugiyono (2009), the sample is part of the population. The sampling used in this study using the population as a saturated sample. Saturated sampling is a sampling technique when all members of the population are used as samples, because the total population in this study only amounted to 45 employees.

\section{Data collection technique}

Data collection techniques are a conscious effort to collect data systematically with standard procedures (Arikunto, 2010), data collection in research is very important because it relates to the availability of data needed to answer research problems. Based on the type of data source required, the data collection techniques used in this study are as follows:

Questionnaire is an information gathering technique that allows the analysis of the attitudes, beliefs, behaviors, and characteristics of some of the main people in the organization who are usually affected by the existing system.

The measurement scale of the research instrument (tool) used is using the Likert scale. According to Sugiyono (2010), the Likert scale is used to measure the nature, income, and perceptions of a person or group of people about social phenomena, the answers to each instrument using a Likert scale have very positive to very negative gradations in the form of words.

\section{Variable Operational Definition}

Table 1

Definition of Operational Variables

\begin{tabular}{|l|l|l|l|}
\hline \multicolumn{1}{|c|}{ Variable } & \multicolumn{1}{|c|}{ Definition } & \multicolumn{1}{c|}{ Indicator } & Measuring scale \\
\hline $\begin{array}{l}\text { Leadership } \\
\text { style (X1) }\end{array}$ & $\begin{array}{l}\text { Leadership style is } \\
\text { a behavior that is } \\
\text { shown by the head } \\
\text { of the employee } \\
\text { with the aim of } \\
\text { influencing his } \\
\text { subordinates so } \\
\text { that they can be } \\
\text { directed properly. }\end{array}$ & $\begin{array}{l}\text { 1. Openness } \\
\text { 2. Work freedom } \\
\text { 3. Participate } \\
\text { 4. Responsibility } \\
\text { 5. Decision-making. } \\
\text { White \& Hippit (2013) }\end{array}$ & Likert scale \\
& $\begin{array}{l}\text { Incentives are } \\
\text { elements or } \\
\text { remuneration } \\
\text { provided on an }\end{array}$ & $\begin{array}{l}\text { 1. Bonus } \\
\text { 2. Length of work } \\
\text { Incentive } \text { Seniority }\end{array}$ & Likert scale \\
(X2) & & \\
& & \\
\hline
\end{tabular}




\begin{tabular}{|c|c|c|c|}
\hline & $\begin{array}{l}\text { irregular or } \\
\text { variable basis } \\
\text { depending on the } \\
\text { work performance } \\
\text { of the employees. }\end{array}$ & $\begin{array}{l}\text { 5. Fairness and Worthiness } \\
\text { Rivai }(2008)\end{array}$ & \\
\hline $\begin{array}{l}\text { Motivation } \\
\text { (X3) }\end{array}$ & $\begin{array}{l}\text { Motivation is a } \\
\text { stimulant of desire } \\
\text { (want) the driving } \\
\text { force of a person's } \\
\text { willingness to } \\
\text { work, each motive } \\
\text { has a specific goal } \\
\text { to be achieved. }\end{array}$ & $\begin{array}{l}\text { 1. Work attitude } \\
\text { 2. Time Discipline and } \\
\text { absence } \\
\text { 3. Mental skills } \\
\text { 4. Initiative } \\
\text { 5. Work knowledge } \\
\text { Sutrisno (2009:32) }\end{array}$ & Likert scale \\
\hline $\begin{array}{l}\text { Work } \\
\text { performance } \\
\text { (Y) }\end{array}$ & $\begin{array}{l}\text { Work } \\
\text { performance is a } \\
\text { result of work } \\
\text { achieved by a } \\
\text { person in carrying } \\
\text { out the work } \\
\text { assigned to him }\end{array}$ & $\begin{array}{l}\text { 1. Quality } \\
\text { 2. Quantity } \\
\text { 3. Task execution } \\
\text { 4. Responsibility } \\
\text { 5. Cooperation } \\
\quad \text { Nasution (2000:99) }\end{array}$ & Likert scale \\
\hline
\end{tabular}

\section{RESEARCH RESULT}

Data Quality Test Results

a. Validity test

Table 2

Validity Test Results

\begin{tabular}{|l|l|r|r|l|}
\hline No & Variables / Indicators & r Count & r Table & Information \\
\hline \multicolumn{5}{|l|}{ Leadership Style } \\
\hline 1 & 1 & 0.433 & 0.294 & Valid \\
\hline 2 & 2 & 0.634 & 0.294 & Valid \\
\hline 3 & 3 & 0.809 & 0.294 & Valid \\
\hline 4 & 4 & 0.725 & 0.294 & Valid \\
\hline 5 & 5 & 0.772 & 0.294 & Valid \\
\hline Incentive & 0.687 & 0.294 & Valid \\
\hline 1 & 1 & 0.548 & 0.294 & Valid \\
\hline 2 & 2 & 0.669 & 0.294 & Valid \\
\hline 3 & 3 & 0.569 & 0.294 & Valid \\
\hline 4 & 4 & 0.305 & 0.294 & Valid \\
\hline 5 & 5 &
\end{tabular}




\begin{tabular}{|l|l|l|l|l|}
\hline \multicolumn{6}{|l|}{ Work motivation } \\
\hline 1 & 1 & 0.516 & 0.294 & Valid \\
\hline 2 & 2 & 0.586 & 0.294 & Valid \\
\hline 3 & 3 & 0.570 & 0.294 & Valid \\
\hline 4 & 4 & 0.607 & 0.294 & Valid \\
\hline 5 & 5 & 0.532 & 0.294 & Valid \\
\hline \multicolumn{5}{|l|}{} \\
\hline 1 & 1 & 0.410 & 0.294 & Valid \\
\hline 2 & 2 & 0.518 & 0.294 & Valid \\
\hline 3 & 3 & 0.666 & 0.294 & Valid \\
\hline 4 & 4 & 0.410 & 0.294 & Valid \\
\hline 5 & 5 & 0.418 & 0.294 & Valid \\
\hline
\end{tabular}

Primary data sources, processed 2020

Table 2 shows that the correlation between each indicator on the construct score of each variable shows significant results, and shows that $r$ count $>r$ table. So it can be concluded that all question items are declared valid.

\section{b. Reliability Test}

Table 3

\section{Reliability Test}

\begin{tabular}{|l|l|l|}
\hline Variable & Alpha & \multicolumn{1}{|c|}{ Information } \\
\hline Leadership Style & 0.827 & Reliable \\
\hline Incentive & 0.699 & Reliable \\
\hline Work motivation & 0.706 & Reliable \\
\hline Work performance & 0.601 & Reliable \\
\hline
\end{tabular}

Primary data sources, processed 2020

The results of the reliability test show that all variables have a fairly large Alpha coefficient, which is above 0.60 so that it can be said that all measurement concepts of each variable and questionnaire are reliable so that furthermore the items in each variable concept are feasible to be used as measuring tools.

\section{Classic Assumption Test Results}

a. Normality test

Figure 2

Probability Plot Chart 


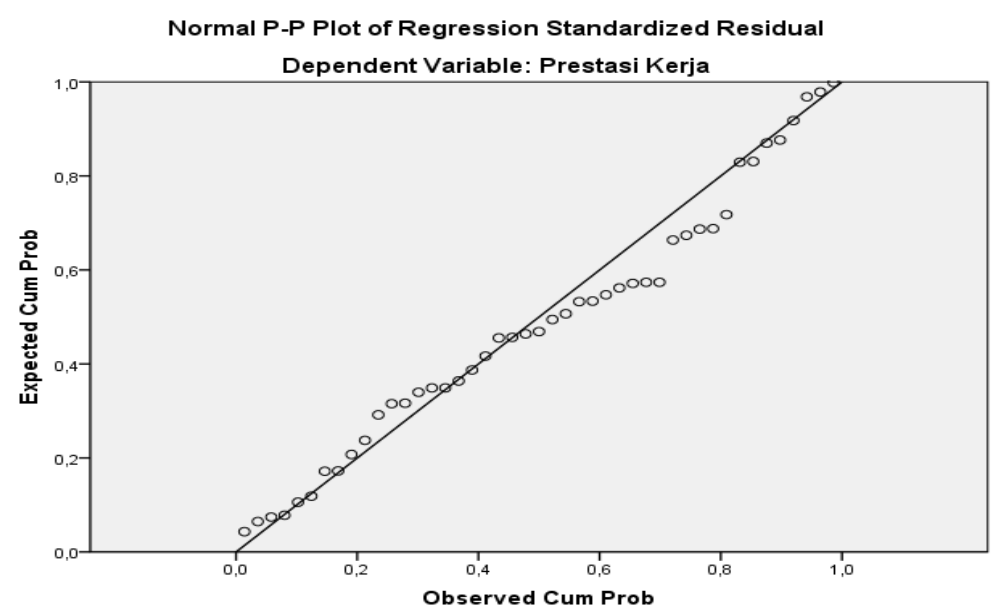

From the figure, it is found that all data are normally distributed, the distribution of data is around the diagonal line.

\section{b. Multicollinearity Test}

\section{Table 3}

\section{Multicollinearity Test}

\begin{tabular}{|l|l|l|}
\hline Independent Variable & Tolerance Value & VIF value $(\%)$ \\
\hline Leadership Style & 0.658 & 1,519 \\
\hline Incentive & 0.669 & 1,494 \\
\hline Work motivation & 0.970 & 1.031 \\
\hline
\end{tabular}

Source: Primary Data, processed 2020

The table shows that the VIF value of all independent variables in this study is less than 10 while the tolerance value of all independent variables is more than $10 \%$, which means that there is no correlation between independent variables whose value is more than $90 \%$, thus it can be concluded that there is no correlation between the independent variables. symptoms of multicollinearity between independent variables in the regression model. 


\section{c. Heteroscedasticity Test}

Figure 3

\section{Heteroscedasticity Test}

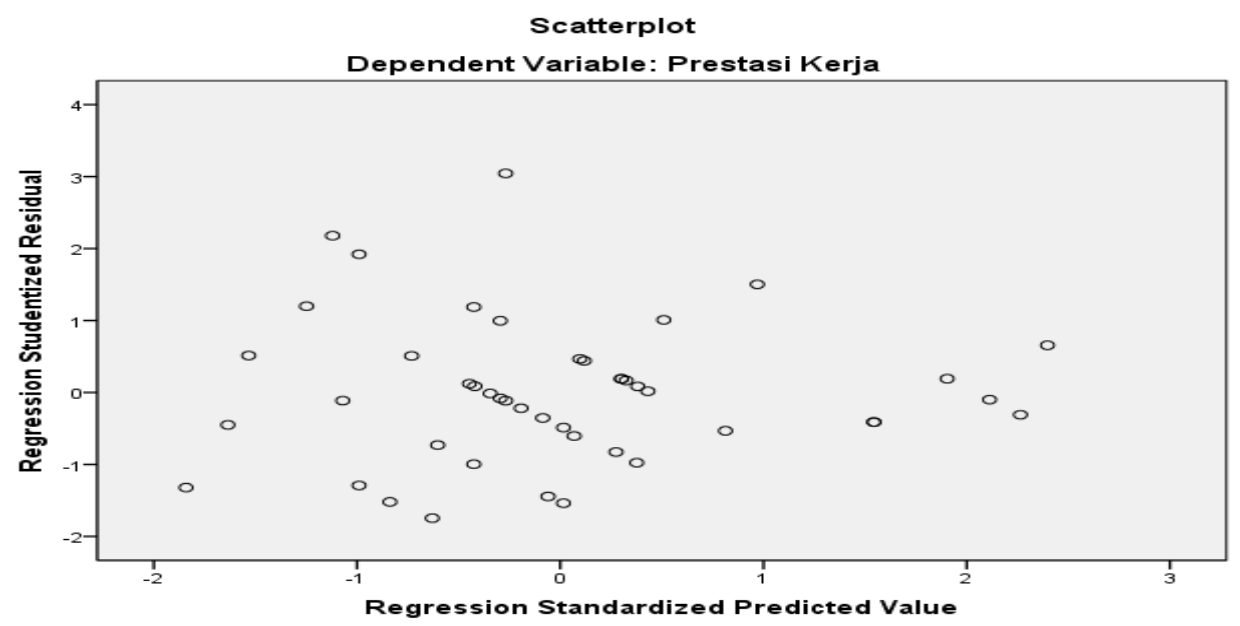

From the graph, it can be seen that the points spread randomly, and are spread both above and below the number 0 (zero) on the $\mathrm{Y}$ axis. This means that there is no deviation from the classical assumption of heteroscedasticity in the regression model made, in other words accepting the homoscedasticity hypothesis.

\section{Data Analysis Results}

a. Multiple Regression Analysis

\section{Table 4}

\section{Multiple Regression Analysis Results}

\begin{tabular}{|c|c|c|c|c|c|}
\hline \multirow[t]{2}{*}{ Model } & \multicolumn{2}{|c|}{$\begin{array}{l}\text { Unstandardized } \\
\text { Coefficients }\end{array}$} & \multirow{2}{*}{\begin{tabular}{|c}
$\begin{array}{c}\text { Standardiz } \\
\text { ed } \\
\text { Coefficien } \\
\text { ts }\end{array}$ \\
Beta
\end{tabular}} & \multicolumn{2}{|c|}{ Collinearity Statistics } \\
\hline & B & $\begin{array}{l}\text { Std. } \\
\text { Error }\end{array}$ & & $\begin{array}{c}\text { Toleran } \\
\text { ce }\end{array}$ & VIF \\
\hline $\begin{array}{cc}1 & \text { (Constan } \\
\mathrm{t})\end{array}$ & $-4,947$ & 2,916 & & & \\
\hline $\begin{array}{c}\text { Leadersh } \\
\text { ip Style }\end{array}$ & ,356 & ,092 & ,443 &, 658 & 1,519 \\
\hline Incentive & ,323 & 095 & ,387 & ,669 & 1,494 \\
\hline $\begin{array}{c}\text { Motivati } \\
\text { on }\end{array}$ & ,451 &, 115 & ,373 & ,970 & 1.031 \\
\hline
\end{tabular}

Source: Primary Data, processed 2020 
The results of the regression test were carried out to measure the linear relationship between the variables of Work Motivation (X1), Job Satisfaction (X2), and Compensation (X3) on Work Productivity (Y). Based on table 4.13 the regression equation obtained is:

$$
Y=+.443 \times 1+.387 \times 2+.373 \times 3
$$

Information:

$$
\begin{aligned}
& Y=\text { Work Performance } \\
& X 1=\text { Leadership Style } \\
& X 2=\text { Incentive } \\
& X 3=\text { Motivation }
\end{aligned}
$$

From these equations it can be explained that:

a. Variables of Leadership Style, Incentives and Motivation have a positive direction towards Employee Work Performance.

b. The Leadership Style Coefficient gives a value of 0.443 which means that if the leadership style is getting better with the assumption that other variables are fixed, the employee's work performance will increase.

c. The Incentive Coefficient gives a value of 0.387 which means that if the Incentive is getting better with the assumption that other variables are fixed, the employee's work performance will increase.

d. The work motivation coefficient gives a value of 0.373 which means that if the work motivation gets better with the assumption that other variables remain, the employee's work performance will increase.

\section{b. Coefficient of Determination Test Results}

\section{Table 5}

\section{Coefficient of Determination Test}

\begin{tabular}{|c|c|c|c|c|}
\hline \multicolumn{5}{|c|}{ Model Summary } \\
\hline Model & $\mathrm{R}$ & R Square & $\begin{array}{c}\text { Adjusted R } \\
\text { Square }\end{array}$ & std. Error of the Estimate \\
\hline 1 & $.802 \mathrm{a}$ & .643 &, 617 & 0.966 \\
\hline \multicolumn{5}{|c|}{ a. Predictor : (Constant), Safety and health, Surveillance } \\
\hline
\end{tabular}

Source: Primary Data, processed 2020

The results of the regression calculation can be seen that the coefficient of determination (Adjusted R2) obtained is 0.617 . This means that $60 \%$ of the variations in employee performance variables can be explained by the variables of Leadership Style, Incentives and Work Motivation. while the remaining $40 \%$ is explained by other variables proposed in this study. 


\section{Hypothesis Testing Results}

a. Simultaneous Test (F Test)

\section{Table 6}

\section{Simultaneous Test Results (F Test)}

\begin{tabular}{|c|c|c|c|c|c|}
\hline \multicolumn{6}{|c|}{ ANOVAb } \\
\hline Model & Sum of Squares & df & Mean Square & $\mathrm{F}$ & Sig. \\
\hline 1 Regression & 68,859 & 4 & 22,953 & 24,605 &, $000 \mathrm{a}$ \\
\hline Residual & 38,252 & 41 & ,933 & & \\
\hline Total & 107,111 & 45 & & & \\
\hline
\end{tabular}

a. Predictors: (Constant), Motivation, Incentives, Leadership Style

b. Dependent Variable: Job Performance

Source: Primary Data, processed 2020

Seen from table 4.15, it can be explained that the calculated $F$ value is $24.605>$ 2.84 with a significant level of $0.000>0.05$, so it can be concluded significantly or together, leadership style, incentives and work motivation affect employee work performance at the Agency's office. Environmental Cleanliness.

\section{b. Partial Test (t Test)}

\section{Table 7}

\section{Partial Test}

Coefficientsa

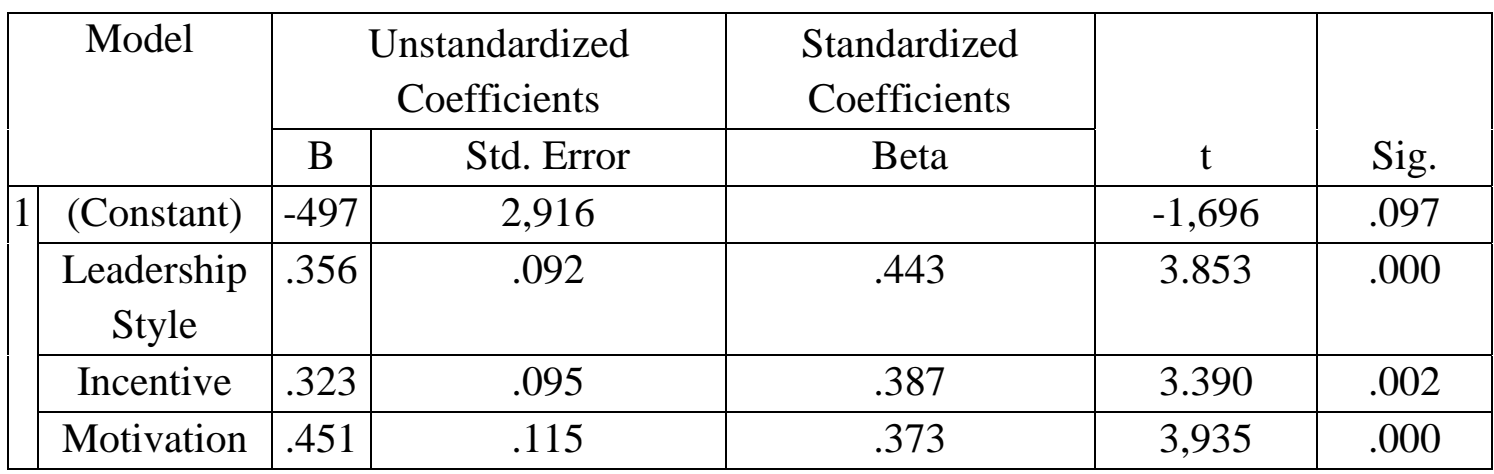

Dependent Variable:Work Performance

Source: Primary Data,2020

\section{Hypothesis Test 1 (H1)}

Table 7 shows the results that testing the leadership style hypothesis shows a tcount value of 3.853 with a significant level of 0.000 . The significant level looks smaller than 0.05 which means that the hypothesis in this study rejects Ho and accepts Ha. Thus it can mean that the hypothesis $\mathrm{H} 1$ that leadership style has a positive influence on employee performance is acceptable. 


\section{Hypothesis Test 2 (H2)}

From table 7, it can be seen that the Incentive hypothesis testing shows a t-count value of 3.390 with a significant level of 0.002 which is smaller than 0.05 , which means that in this study accepts Ha and rejects Ho. Thus, it means that incentives have a positive effect on employee performance.

\section{Hypothesis Test 3 (H3)}

From table 7, it can be seen that the motivational hypothesis testing shows the t-count value of 3.935 with a significant level of 0.000 , which is smaller than 0.05 , which means that in this study accept $\mathrm{Ha}$ and reject Ho. thus motivation has a positive effect on employee performance.

\section{CONCLUSION}

\section{The Influence of Work Leadership Style on Work Performance}

The results of hypothesis testing (H1) prove that there is a positive influence between leadership style and employee performance. Based on the results of the calculations that have been carried out, it is obtained that the $t$ count is 3.853 with a significant level of 0.000 which is smaller than 0.05 so that $\mathrm{Ha}$ is accepted and Ho is rejected. The results of this test statistically indicate that there is a positive influence on the leadership style according to the position that will affect employee performance. this is supported by previous research by Sonny Rompas (2008). Which examines the influence of the sub-district leadership style on employee performance at the Malalayang sub-district office. with the analysis that leadership style has a significant positive effect on employee performance.

In the results of previous research supported by Dirga Lestari (2015), namely the analysis of the influence of leadership style on employee work performance (Study on Cooperatives. With the analysis that leadership style has a significant positive effect on employee work performance. And the results of the latest research and supported by Diah Ayu Liawati (2013) the influence of leadership style and motivation on employee performance at the regional office of the provincial directorate general of the treasury in Yogyakarta, with an analysis that leadership style has a positive influence on employee work performance.

\section{Influence of Incentives on Work Performance}

Based on the results of the hypothesis $(\mathrm{H} 2)$, it shows that there is an influence between incentives and employee performance. The results of the calculations that have been carried out are obtained t count of 3.390 with a significant level of 0.002 is smaller than 0.05 so that $\mathrm{Ha}$ is accepted and $\mathrm{Ho}$ is rejected. This test statistically proves that there is a positive influence between incentives and employee performance. In this case, incentives greatly affect employee performance. because the incentives received have fulfilled the desire of the job in completing a job because it has affected employee performance. the results of this study are in accordance with the results of research by Muhammad Kastalani (2015:351-364). which examines the effect of incentives on work performance in the regional disaster management agency in the city of Samarinda. 
In a previous study supported by Rahmad Rozi (2012) the effect of incentives on employee performance at PT. Indah Cargo Kota Pekanbaru. Where in this study shows that the incentive variable has a positive and significant effect on employee performance. And in the last previous study supported by Widiana Kusuma Wardani (2017), the effect of incentives on the work performance of Ameera Pekanbaru hotel employees. Where in this study shows that the incentive variable has a positive and significant effect on employee performance.

\section{The Influence of Work Motivation on Employee Work Performance}

Testing the data that has been carried out on the hypothesis test (H3) proves that there is an influence of motivation on employee performance. the results of the statistical test calculation obtained t count of 3.935 with a significant level of 0.000 less than 0.05 , so Ha is accepted and Ho is rejected. Testing this hypothesis statistically proves the influence of motivation on employee performance. Based on the respondents' responses, the motivation given by the company is very helpful for employees in doing a job. The results of this study are in accordance with the results of research conducted by John Montolalu (2015) The effect of motivation on employee performance in a study at PT. Pos Indonesia Type C Manado, where this study shows that motivational variables simultaneously affect employee performance.

In the study, the results of previous research, namely the research of Ibnu Sina (2015) the effect of motivation on the work performance of employees of the Department of Highways and Waterworks of Samarinda City. Where this research shows that the motivation variable has a significant effect on employee performance. In previous research, in Yani Hartanti's research (2016). the effect of motivation on employee performance at PT. Palembang Branch Sharia Procurement. Where this research shows that the motivation variable has a significant effect on employee performance.

\section{CLOSING}

\section{Conclusion}

Based on the results of the analysis and discussion that have been described previously, several conclusions will be presented based on the most dominant value then followed by the next value, which is as follows:

1. Leadership Style has a positive and significant effect on Employee Work Performance at the Office of the Environment Agency (BLHK) Langsa City.

2. Incentives have a positive and significant effect on employee performance at the Langsa City Environmental Agency (BLHK) Office.

3. Work Motivation has a positive and significant effect on Employee Work Performance at the Office of the Environmental Agency (BLHK) Langsa City.

4. The most dominant research result is that work motivation has an effect on Employee Performance at the Office of the Environmental Agency (BLHK) of Langsa City.

\section{Suggestion}

After the research has been conducted, some suggestions can be put forward as follows: 
1. Employees at the Office of the Environment Agency (BLHK) Langsa City. should further improve cleanliness in order to realize a decent residential community and organize a harmonious and sustainable living environment. In order to be able to complete work effectively and efficiently so that work performance at the office can be satisfactory and have good goals in every company.

2. Employees feel that the incentives that have been received have been fulfilled in the office of the environmental agency in the city of Langsa. but suggestions from superiors employees must complete the job even better than at the end of each month. So that the incentives received will be similar to the work done by employees.

3. So that superiors in the office of the environmental agency in the city of Langsa should pay more attention to a motivation that has been given by superiors to employees. then employees must be more thorough and very good at doing a job so that the office can produce good work performance.

4. So that employees can do a good job and can improve employee performance in the office of the environmental agency.

\section{REFERENCE}

Arikunto, S. (2010). Prosedur Penelitian Suatu Pendekatan Praktik. Jakarta: Rineka Cipta. Ardana, 1 komang., Mujiati Dan Utama Murdiatha 1 Wayan 2012. Manajemen Sumber Daya Manusia. Yokyakarta: Ghaha Ilmu.

Colquitt., Lepine. \& Wesson. (2009). Organizational Behavior. New York: Mcgraw-Hill.

Dharma, Agus, 2012, Manajemen Sumber Daya Manusia. Ghlia Indonesia, Jakarta.

Dessler, (2013). Manajemen Sumber Daya Manusia : Buku 1.Jakarta:Indeks.

Dessler, (2010). Manajemen Sumber Daya Manusia : Buku 1.Jakarta:Indeks.

Ghozali, Imam. (2011). Aplikasi Analisis Multivariate Dengan Program Ibm Spss19. Badan Penerbit Universitas Diponegoro, Semarang

Ghozali, Imam. (2009). “Aplikasi Analisis Multivariate dengan program SPSS”. Semarang : UNDIP.

Handoko, (2001). Manajemen ; Edisi Kedua, Cetakan Ketiga Belas, BPFE, Yogyakarta.

Handoko, M.B.A. (2012). Manajemen Personalia Dan Sumber Daya Manusia. Cetakan Kedelapan Belas. BPFE, Yogyakarta.

Hariandja, M. (2011). Manajemen Sumber Daya Manusia. Bumi Aksara, Jakarta.

Hasibuan, H. Malayu Sp. (2005). Manajemen Sumber Daya Manusia. Bumi Aksara, Jakarta.

Hasibuan, Malayu S.P. 2006. Manajemen Dasar, Pengertian, dan Masalah, Edisi Revisi. Jakarta; Bumi Aksara.

Hasibuan, Malayu Sp.(2012). Manajemen: Dasar, Pengertian, dan Masalah. Jakarta: PT. Aksara.

Mangkunegara, Abraham Maslow (2011) Manajemen Sumber Daya Manusia Perusahaan, Cetakan keenam. Remaja Rosda Karya: Bandung. 
Panggabean, Mutiara Sibarani (2010) Manajemen Sumber Daya Manusia,Cetakan Pertama: Oktober. Ghalia Indonesia.

Nawawi. (2011). Manajemen Sumber Daya Manusia: Untuk Bisnis Yang Kompetitif. Yogyakarta: Gajah Mada University Press.

Nawawi. (2013). Manajemen Sumber Daya Manusia Yogyakarta: Gajah Mada University Press.

Robbins, S.P. (2007) Perilaku Organisasi Buku 1. Jakarta: Salemba Empat Hal 222.232.

Robbins, Steven P. Dan Timoty A. Judge (2011). Perilaku Organisasi, Jakarta: Salemba Empat. Rahmad Rozi .(2017). Pengaruh Insentif Terhadap Prestasi Kerja Karyawan Pada PT. Indah Cargo Kota Pekanbaru. E-journal Administrasi Bisnis, $\quad$ 2017, (3) : 401-415. Fakultas Ilmu Sosial Dan Ilmu Politik Universita Mulawarman.

Rianty Kusumah Dewi. (2014) Pengaruh Motivasi Terhadap Prestasi Kerja Karyawan Pada Badan Perencanaan Pembangunan Daerah (Bapedda) Kota Bandung. Jurnal Univesitas Tulungagung Bonorowo Vol.1.No.1.Tahun 2014.

Sri Suranta, 2002. "Dampak Karyawan Pada Hubungan Antara Gaya Kepemimpinan Dengan Kinerja Karyawan Perusahaan Bisnis”.Vol 15, No 2, Hal 116-126.

Sutrisno, E. (2012) Manajemen Sumber Daya Manusia. Surabaya: Gramedia.

Sugiyono. (2010).Metode Penelitian Kuantitatif, Kualitatif, dan RND. Bandung: Alfabeta. (2009). Statistika untuk Penelitian. Bandung :Alfabeta.

Yusuf, M., Paranoan, D, B., Dan Margono.2015. Pengaruh motivasi dan disiplin kerja, pada kantor dinas kesehatan sangatan kabupaten kutai timur. E. Jurnal Aministrative reform. Vol 2, No. 3. 